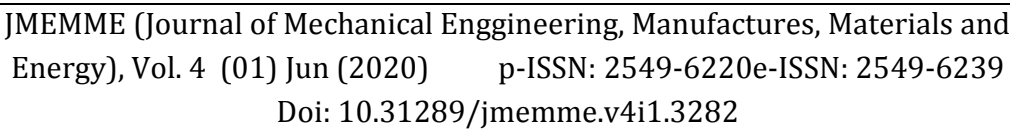

JMEMME (Journal of Mechanical Engineering, Manufactures, Materials and Energy)

\title{
Analisa Dampak Penurunan Kinerja Lube Oil Cooler pada Turbin di PLTU Belawan
}

\section{Analysis of Impact Reduced Performance of the Lube Oil Cooler on Turbin at PLTU Belawan}

\author{
Husin Ibrahim11*, Amirsyam Nasution2), Indra Hermawan³), Muhammad Idris' ${ }^{4)}$ \\ 1) Program Studi Teknik Mesin, Politeknik Negeri Medan (POLMED) \\ 2,3,4) Program Studi Teknik Mesin, Fakultas Teknik, Universitas Medan Area \\ Diterima: 02-01-2020 ; Disetujui: ; Diterbitkan: 30-06-2020 \\ *Corresponding author: husinibrahim@yahoo.co.id
}

\begin{abstract}
Abstrak
Lube oil cooler adalah cross flow compact heat exchanger yang berfungsi untuk melepaskan panas yang dibawa oleh minyak pelumas dialirkan melalui sisi shell menuju sisi tube dengan fluida pendingin air demin dimana masing-masing cairan dipisahkan di dalam lube oil cooler. PT. PLN Sektor Pembangkit Belawan merupakan salah satu unit pembangkit tenaga listrik di wilayah Sumatera Utara yang kinerja dan kehandalannya sangat penting untuk menjamin kelangsungan pasokan listrik. Dari penelitian ini, rasio koefisien perpindahan panas disisi shell dan pipa tube serta efektivitas perpindahan panas yang terjadi dapat diketahui dengan menganalisa temperatur masuk dan keluar aliran air pendingin dan minyak pelumas dapat ditentukan. Selain itu dampak dan penyebab penurunan kinerja lube oil cooler dapat diketahui. Penelitian ini berfokus pada analisis data temperatur masuk dan keluar pendingin minyak pelumas dan tekanan diferensial yang tercermin dari data operasional yang dikumpulkan dari ruang kontrol lembar kertas PLTU Belawan. Koefisien perpindahan panas disisi shell (hh) sebesar $7.585,32 \mathrm{~W} / \mathrm{m} 2 \mathrm{~K}$, kehilangan panas total disisi shell (hl,total) sebesar $66,38 \mathrm{~m}$. Koefisien perpindahan panas disisi tube (hi) sebesar 11.460,98 W/m2K dan kehilangan panas total disisi tube (hl,total) sebesar $14,82 \mathrm{~m}$.
\end{abstract}

Kata Kunci: lube oil cooler, heat exchanger, koefisien perpidahan panas

\begin{abstract}
Lube oil cooler is a cross flow compact heat exchanger which serves as heat transmitter that brought by lubricants oil that flow around shell's side to water-demin-cooler around the tube, each fluid separated inside the lube oil cooler. PT.PLN's Belawan Generator Sector is one of the power plant units in the North Sumatera region that its performance and reliability very critical to ensure the electricity supply's continuity. From this research, heat transfer coefficient around tube, shell, and effectiveness ratio of heat transfer by analyzing flows of cooling water and lube oil, hopefully can be determined. On another note, the impact(s) and cause(s) of the lube-oil-cooler's decreasing in performance can be identified. This research focuses on analyzing the incoming and outgoing temperature data of lube oil cooler and differential pressure from operational data collected from log sheet control room of PLTU Belawan.
\end{abstract}

Keywords: lubes oil cooler, heat exchanger, heat transfer coefficient

How to Cite: Ibrahim, H.., 2020, Analisa Dampak Penurunan Kinerja Lube Oil Cooler pada Turbin di PLTU Belawan, JMEMME (Journal of Mechanical Enggineering, Manufactures, Materials and Energy), 4(01): 10-23 


\section{PENDAHULUAN}

PT. PLN (Persero) Sektor Pembangkitan Belawan, bergerak dibidang pembangkitan energi listrik yang beroperasi untuk memenuhi kebutuhan energi listrik diwilayah Sumatera Bagian Utara (Sumbagut). Pada sektor ini terpasang sebanyak 4 unit Pembangkit Listrik Tenaga Uap (PLTU) disektor Pembangkitan Belawan dengan daya terpasang masing-masing 65 MW yang menggunakan bahan bakar MFO (Marine Fuel Oil) pada PLTU unit 1 dan 2, sedangkan pada PLTU unit $3 \& 4$ memiliki design berbeda dengan bahan bakar campuran (mixing) MFO dan Nature Gas.

Pada instalasi unit turbin di PLTU, terdapat banyak komponen mesin yang saling bersinggungan yang akan menimbulkan gesekan, mudah panas, keausan hingga kerusakan material saat beroperasi penuh. Setiap gesekan dan kenaikan temperatur kerja turbin akan mempengaruhi temperatur minyak pelumas serta performance turbin.

Sistem pelumasan berfungsi mensupply minyak pelumas bersih bertekanan dengan temperatur tertentu kedalam bearing turbin, bearing alternator, bearing kompresor, bearing Load Gear, dan sistem lainnya. Selain itu minyak pelumas juga berfungsi sebagai media pendingin. Temperatur seluruh komponen yang dilalui minyak pelumas akan diserap dan dibawa bersama dengan aliran minyak pelumas. Selanjutnya kenaikan temperatur minyak pelumas tersebut akan diturunkan kembali oleh lube oil cooler sampai pada temperatur normal kembali [1].
Proses pendinginan minyak pelumas ini selanjutnya dilakukan melalui alat lube oil cooler dengan menggunakan demin water yang dipasang pada jalur pemipaan minyak pelumas turbin. Oleh karenanya latar belakang dari penelitian ini adalah untuk menganalisa proses perpindahan panas (heat transfer rate) pada sistem lube oil cooler, dan mengambil judul Analisa Dampak Penurunan Kinerja Lube Oil Cooler pada Turbin di PLTU Belawan.

Hukum Kekekalan Energi (Hukum I Thermodinamika) berbunyi: "Energi dapat berubah dari satu bentuk energi ke bentuk energi yang lain tetapi tidak bisa diciptakan atau dimusnahkan (konversi energi)". Sedangkan bila dalam sebuah sistem tertutup“jumlah energi tidakdapat berubah, ia akan tetap sama". Proses perpindahan kalor/panas pada kondisi tertentu menandakan adanya perpindahan energi karena beda temperatur di antara benda/material. Dengan demikian perpindahan kalor dapat didefinisikan sebagai proses berpindahnya suatu energi (kalor) dari satu benda ke benda lain akibat perbedaan temperatur tertentu [2].

Pada lube oil cooler turbin PLTU unit 3 PT PLN Belawan, terjadi proses perpindahan panas secara tidak langsung dimna fluida bertemperatur panas (minyak pelumas) didinginkan dengan cara dialirkan melalui sisi shell (menyelimuti sisi luar pipa-pipa tube) sedangkan fluida pendingin (air demin) dialirkan melalui sisi dalam pipa-pipa tube, seperti diperlihatkan pada gambar 1. Material pipa-pipa tube yang digunakan adalah tembaga atau aluminium yang memiliki konduktivitas 
termal tinggi sehingga efektivitas pertukaran panas sangat baik [3].

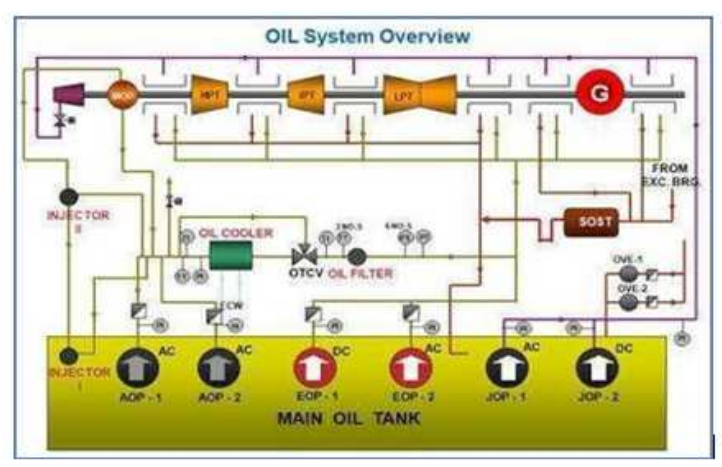

Gambar 1. Sistem Pelumasan pada PLTU Unit-3 PT. PLN Belawan

Gambar 1 adalah alur proses kerja fluida masuk pada pipa-pipa tube berisi fluida pendingin (air demin) sedangkan pada sisi shell berisi fluida panas (minyak pelumas) didalam lube oil cooler (Gambar 2).

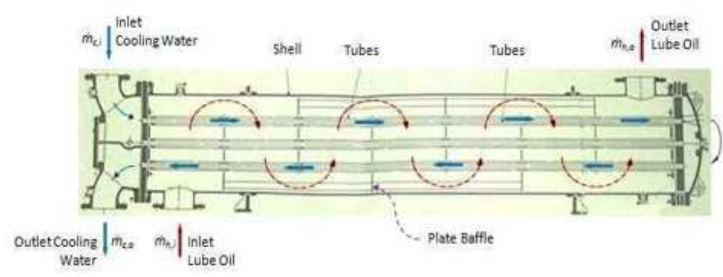

Gambar 2. Alur proses kerja fluida masuk dan keluar pada lube oil cooler

Dilihat dari diagram alur proses kerja lube oil cooler diatas dapat diamati bahwa proses pelepasan panas oleh minyak pelumas dan penyerapan panas oleh air pendingin terjadi secara bersilangan, dimana arah aliran fluida panas (minyak pelumas) dialirkan naik turun bersirkulasi menyelimuti sisi luar pipa-pipa tube sedangkan fluida pendingin (demin water) bergerak lurus didalam pipa-pipa tube yang tidak dapat bersinggungan langsung (tidak bercampur) antara fluida panas dengan fluida pendingin [4].
Jumlah dan susunan pipa-pipa tube dan shell didesign bertujuan untuk menentukan berapa lama kedua fluida dialir didalam lube oil cooler untuk saling melepas dan menyerap panas. Untuk menentukan nilai TLMTD pada lube oil cooler jenis ini dapat digunakan persamaan 1.

$$
\mathrm{T}_{\mathrm{LMTD}}=\frac{\Delta \mathrm{T}_{2}-\Delta \mathrm{T}_{1}}{\mathrm{Sn} \frac{\Delta \mathrm{T}_{2}}{\Delta \mathrm{T} 1}}
$$

dimana : $\Delta \mathrm{T} 2=(\mathrm{T} 1-\mathrm{T} 4)$ dan $\Delta \mathrm{T} 1=(\mathrm{T} 2$ - T3).

Untuk menganalisa efektivitas alat penukar kalor dengan pendekatan LMTD (Log Mean Temperature Difference) dihitung dengan menentukan temperatur rata-rata fluida untuk jumlah kalor yang dipindahkan dengan persamaan 2 [5].

$$
\text { LMTD }=\frac{\left(\mathrm{l}_{1}-\mathrm{t}_{1}\right)-\left(\mathrm{I}_{2}-\mathrm{t}_{2}\right)}{\ln \left(\frac{\left(\mathrm{T}_{1}-\mathrm{t}_{1}\right)}{\left(\mathrm{T}_{2}-\mathrm{t}_{2}\right)}\right)}
$$

Analisa perpindahan panas alat penukar kalor dengan metode NTU juga dapat digunakan untuk memilih jenis alat penukar kalor/panas yang lebih tepat. Efektifitas metode NTU didefinisikan perbandingan perpindahan panas nyata dibagi perpindahan panas maksimum [6].

Perpindahan panas nyata :

$$
Q=\dot{m}_{h} . C_{h} \cdot\left(T_{h 1}-T_{h 2}\right)=\dot{m}_{c} \cdot C_{c} \cdot\left(T_{c 1}-T_{c 2}\right)
$$

Perpindahan panas maksimum :

$$
Q_{\text {maks }}=(\dot{m} . C)_{\min } \cdot\left(T_{h 1}-T_{c 1}\right)
$$

\section{METODE}


Pelaksanaan penelitian berlokasi di PT. PLN (Persero) Sektor Pembangkitan Belawan, Jl. Pulau Sicanang No. 1 Belawan - Sumatera Utara - Indonesia. Lokasi tersebut diperlihatkan pada gambar 3.

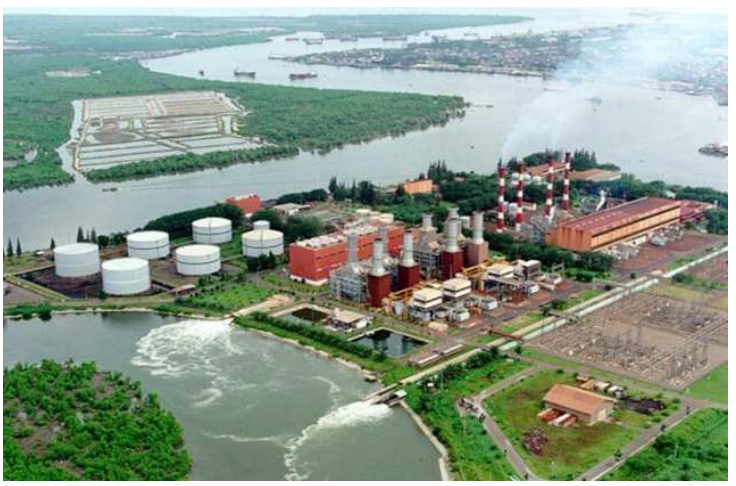

Gambar 3. Potret udara lokasi PT. PLN (Persero) Sektor Pembangkitan Belawan

Penelitian dan pengamatan bertujuan untuk mengumpulkan datadata berupa logsheet harian diantaranya temperatur fluida kerja di sisi masuk dan keluar lube oil cooler serta tekanan differensial yang terjadi pada Seal Oil System berdasarkan operasional unit di control room PLTU milik PT. PLN (Persero) Sektor Pembangkitan Belawan dan pengecekan langsung dilapangan.

Peralatan yang digunakan adalah: Lube oil cooler (gambar 4), sebagai alat penukar panas dari minyak pelumas turbin yang merupakan objek utama dalam penelitian ini, dilengkapi dengan pressure gauges untuk mengetahui tekanan fluida minyak pelumas dan air pendingin yang bekerja pada lube oil cooler.

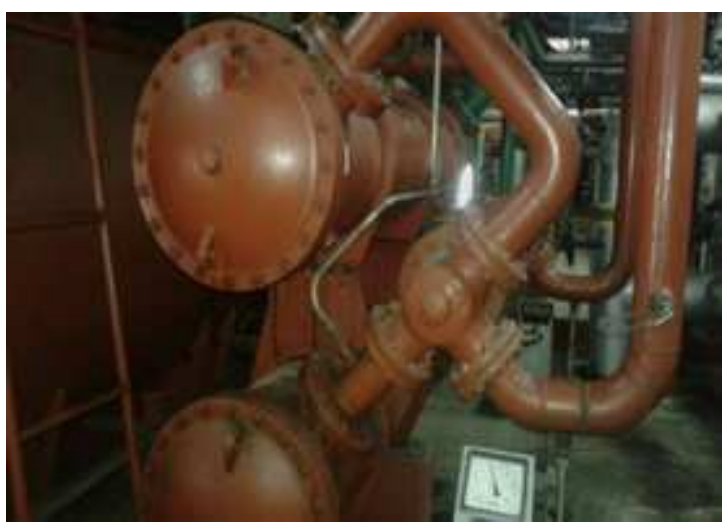

Gambar 4. Lube Oil Cooler pada PLTU

Komputer untuk membaca data (gambar 5), mengumpulkan dan mengolah data dari thermometer dan pressure gauges pada unit lube oil cooler. Komputer juga untuk memonitor, mengendalikan dan memastikan bahwa kondisi pembangkit berada dalam performa terbaik.

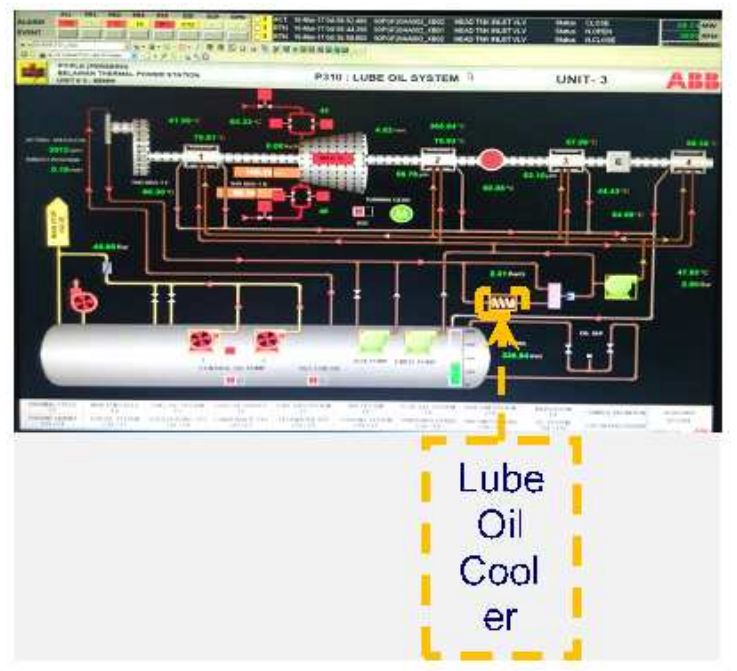

Gambar 5. Tampilan layar komputer ketika memonitor kinerja turbin di Control Room PLTU

Digital Infrared Thermometer (Gambar 6), untuk mengukur temperatur secara manual fluida minyak pelumas dan demin water disisi masuk dan keluar, dilokasi lube oil cooler terpasang. Hal ini diperlukan sebagai double checking antara pengukuran 
dilapangan dengan hasil pembacaan pada panel di control room.

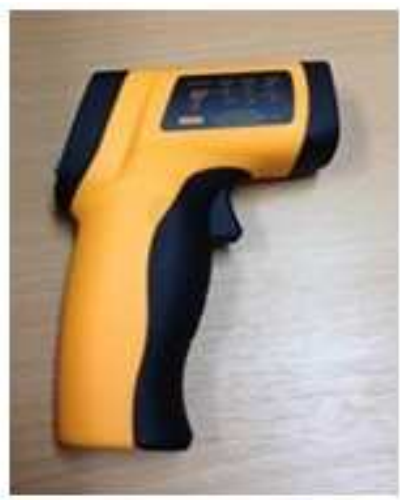

Gambar 6. Digital Infrared Thermometer

Pressure gauges, berfungsi untuk mengetahui tekanan differensial minyak pelumas dan air pendingin yang bekerja didalam lube oil cooler.

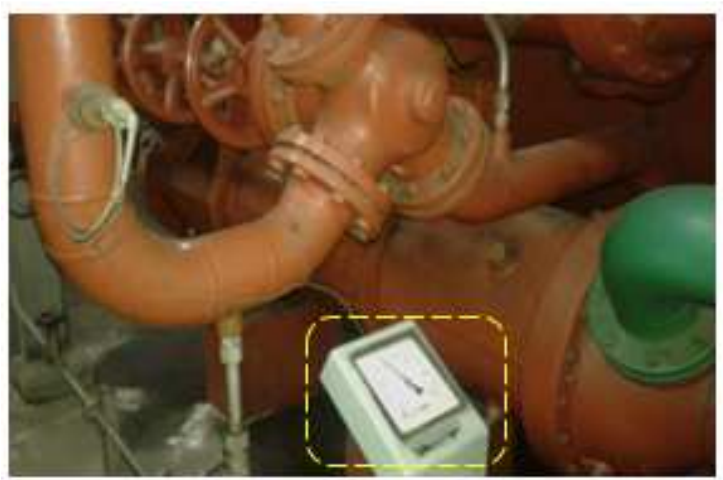

Gambar 7. Pressure Gauges yang dipasang pada lube oil cooler

Bahan yang menjadi objek penelitian adalah demin water sebagai fluida pendingin dan minyak pelumas turbin sebagai fluida panas yang akan dipindahkan sebagian panasnya ke fluida pendingin. Rangkaian alur proses penelitian yang dilakukan pada penelitian ini disajikan dalam bentuk diagram Flow Chart (Gambar 8).

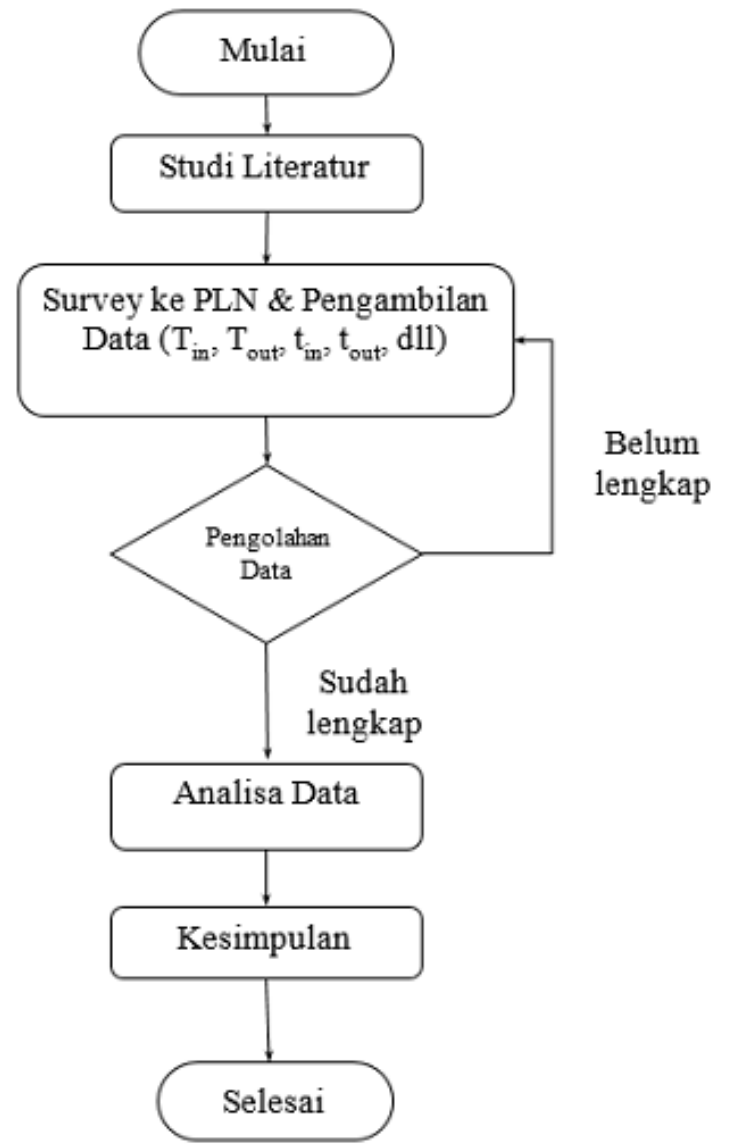

Gambar 8. Flow Chart Penelitian (Diagram Alur Proses Penelitian)

Proses penelitian yang dilakukan dengan tahapan:

- Observasi di PLTU unit 3 PT. PLN (Persero) Sektor Pembangkitan Belawan yaitu mengamati sistem kerja lube oil cooler jenis pendingin demin water serta pengambilan data-data yang dibutuhkan.

- Studi literatur/teori dari buku, jurnal, website, berkaitan dengan dasar hukum kekekalan energi (Hukum I Thermodinamika), proses perpindahan panas (energi), serta garis besar sistem kerja objek lube oil cooler pada turbin dan permasalahan yang dihadapi dilapangan. 
- Pengumpulan data dengan mencatat seluruh data-data yang diperlukan seperti temperatur, tekanan pada minyak pelumas \& air pendingin, koefisien fluida kerja serta data lain yang mendukung sesuai kebutuhan.

- Pengolahan data yaitu mengolah seluruh data yang telah diperoleh dalam penelitian ini dengan merujuk pada referensi berbagai perhitungan, rumusan, untuk mendapatkan nilai laju perpindahan panas total heat transfer rate (Qtotal), efektifitas lube oil cooler, hingga rasio transfer panas pada lube oil cooler.

- Analisa seluruh data yang diperoleh langsung maupun melalui perhitungan dan mengelompokkannya ke dalam suatu pola, kategori dan satuan uraian dasar. Analisa data tersebut selanjutnya disajikan dalam bentuk tabel atau grafik yang mudah dipahami.

- Kesimpulan diperoleh dari hasil perbandingan nilai heat transfer rate antara fluida pendingin dengan fluida panas pada sistem lube oil cooler turbin.

\section{HASIL DAN PEMBAHASAN}

Data diperoleh mulai dari mengambil sampling tiap jam sejak tanggal 03 s/d 07 Juni 2017. Nilai dan parameter data diperoleh di control room PLTU unit 3 Belawan pada lube oil cooler selama unit beroperasi. Data tersebut selanjutnya diinput ke dalam logsheet harian PT PLN. Jika panas yang dilepaskan fluida minyak pelumas sebesar (Q) persatuan waktu, maka panas yang diterima oleh fluida air pendingin sebesar (Q) pula.

Namun demikian kemampuan untuk melepas dan menyerap panas fluida akan dipengaruhi oleh koefisien perpindahan panas keseluruhan, luasan perpindahan panas dan selisih temperatur rata-rata fluida kerjanya. Sedangkan perubahan perpindahan panas, dibatasi pada mekanisme perpindahan panas konveksi sistem sesuai dengan jenis lube oil cooler terpasang. Berikut ini foto lube oil cooler jenis pendingin demin water yang dilakukan penelitian.

Jumlah panas yang diterima cooling water $(\mathrm{Qc})$ :

$\mathrm{Qc}=$ m cc_Cc.(Tc2-Tc1)

$\mathrm{Qc}=0,21 \mathrm{Mw}$

Jumlah panas yang diterima lube oil (Qh) :

$\mathrm{Qh}=\mathrm{mh}$. Ch.(Th1-Th2)

$\mathrm{Qh}=0,24 \mathrm{MW}$

Jumlah panas yang ditransfer $(\mathrm{Qt})$ :

$\mathrm{Qt}=\mathrm{Qc}+\mathrm{Qh}$

$\mathrm{Qt}=0,45 \mathrm{MW}$

Beda rata-rata temperatur kedua fluida $\Delta \mathrm{T}$ atau $\Delta \mathrm{TLMTD}$, adalah $13,47 \mathrm{~K}$.

Untuk cooling surface per apparatus $(\mathrm{A})=94 \mathrm{~m} 2$ (tabel.1), maka koefisien perpindahan panas total (U) adalah 349,33 W/m2.K.

Tabel 1. Dimensi lube oil cooler 
Ibrahim, H..., Analisa Dampak Penurunan Kinerja Lube Oil ...

\begin{tabular}{|c|c|c|c|}
\hline \multicolumn{4}{|c|}{ Data Detail/Dimensi Oil Cooler Unit : $3 \& 4$} \\
\hline \multirow{2}{*}{\multicolumn{2}{|c|}{ 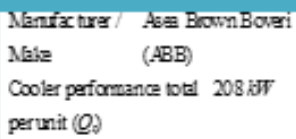 }} & \multicolumn{2}{|c|}{ CROK $6320-2 F$} \\
\hline & & $\begin{array}{l}\text { Tube dimensions } \\
\text { (OD } x \ln x \mathrm{~L})\end{array}$ & $24 \times 1 \times 2000 \mathrm{~mm}$ \\
\hline $\begin{array}{l}\text { Cooling thoes pa } \\
\text { apparans (N) }\end{array}$ & 63 thes & $\begin{array}{l}\text { Diameter har thbe } \\
\text { (d) }\end{array}$ & $24 \mathrm{~mm}$ \\
\hline $\begin{array}{l}\text { Max atlowble working } \\
\text { pressure the side }\end{array}$ & $8 b a$ & $\begin{array}{l}\text { Diameter dalam } \\
\text { tube (A) }\end{array}$ & $22 \mathrm{~mm}$ \\
\hline $\begin{array}{l}\text { No of passes } \\
\text { (Jurlah lahan } N_{y} \text { ) }\end{array}$ & Giaivan & T thal thoe (A) & $1 \mathrm{mon}$ \\
\hline $\begin{array}{l}\text { Cooling suria ce per } \\
\text { apparabs (A) }\end{array}$ & & Panjang tube (L) & $2000 \mathrm{~mm}$ \\
\hline Cooler disposition & honizotal & Cooling water & $\begin{array}{l}\text { losed cirait c w. / } \\
\text { andensate }\end{array}$ \\
\hline
\end{tabular}

Pada tabel di atas, telah diketahui beberapa data seperti debit fluida water cooler $(\mathrm{Qc})=0,067 \mathrm{~m} 3 / \mathrm{s}, \mathrm{di}=0,022 \mathrm{~m}$, $\mathrm{Np}=6$ Laluan, dan Nt $=63$ tubes, $\rho c=$ $992,67 \mathrm{~kg} / \mathrm{m} 3, \mu \mathrm{c}=673 \times 10-6 \mathrm{Ns} / \mathrm{m} 2$. Maka kecepatan aliran (Vc) pada cooling water $16,75 \mathrm{~m} / \mathrm{s}$.

Perpindahan panas juga dapat dipengaruhi oleh tingkat turbulensi aliran dan jumlah tube. Tingkat turbulensi aliran diperoleh dari bilangan Reynold number $\operatorname{Re}=543.534,92(\operatorname{Re}>$ 2300 maka jenis aliran fluida turbulen).

Bilangan Nusselt $(\mathrm{Nu})$ dengan data $\operatorname{Prc}=4,473, \mathrm{kc}=629 \times 10-3 \mathrm{w} / \mathrm{m} . \mathrm{K}$ ialah 400,86. Maka Perpindahan panas konveksi rata-rata aliran fluida yang melewati tube berdasarkan bilangan Nusselt ialah 11.460,98 W/(m².K).

Koefisien gesek disisi tube :

$$
\begin{aligned}
& f=\left[0,79 x \ln \left(\operatorname{Re}_{D}\right)-1,64\right]^{-2} \\
& f=0,0129
\end{aligned}
$$

Kehilangan panas mayor disisi tube:

$$
\begin{aligned}
& h_{l, \text { mavor }}=f \frac{N_{p} x L x\left(V_{c}\right)^{2}}{d_{i} \times 2 \cdot g} \\
& h_{l, \text { mavor }}=100,62 \mathrm{~m}
\end{aligned}
$$

Kehilangan panas minor disisi tube:

$$
\begin{aligned}
& h_{l \text { minor }}=\frac{N_{p} \cdot k \cdot V_{c}{ }^{2}}{2 g} \\
& h_{l \text { minor }}=85,80 \mathrm{~m}
\end{aligned}
$$

Kehilangan panas total disisi tube:

$$
\begin{aligned}
& h_{l, \text { total }}=h_{l, \text { mavor }}-h_{l, \text { minor }} \\
& h_{l, \text { total }}=14,82 \mathrm{~m}
\end{aligned}
$$

Penurunan tekanan disisi tube:

$$
\begin{aligned}
& \Delta p_{\text {tube }}=\rho_{c} \times g \times h_{\text {total }} \\
& \Delta p_{\text {tube }}=144.318,53 \mathrm{~N} / \mathrm{m}^{2}
\end{aligned}
$$

Pengukuran dimensi tube dan arah aliran lube oil didalam unit lube oil cooler akan dilakukan pengukuran seluruh komponen yang dibutuhkan.

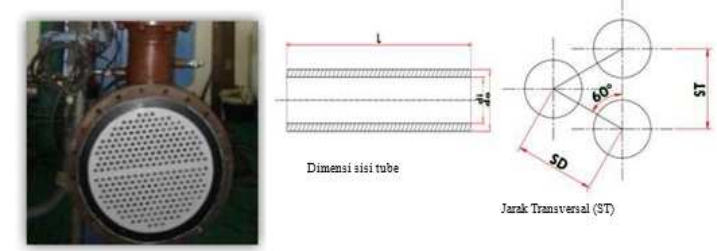

Gambar 7. Dimensi Susunan Pipa Tube didalam Lube Oil Cooler

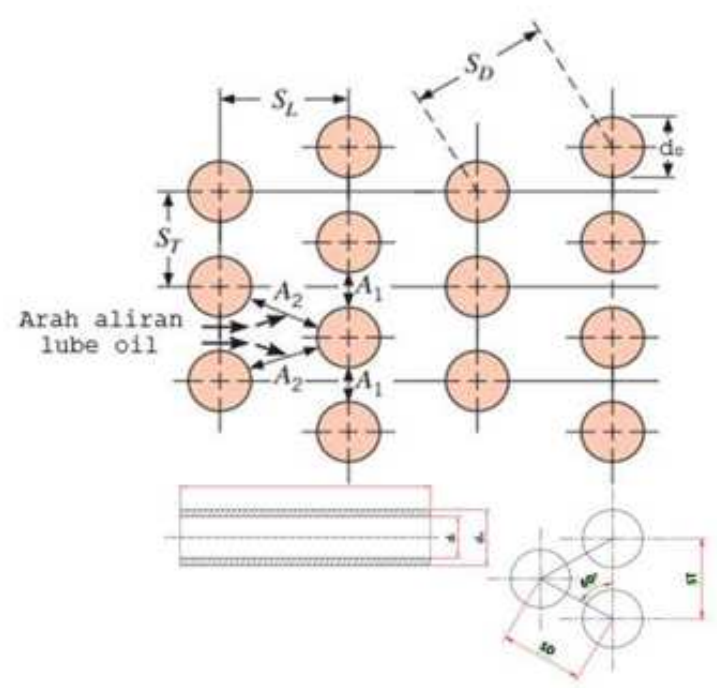

Gambar 8. Detail Perhitungan Dimensi dan Susunan Pipa Tube

Jarak SL dihitung dengan persamaan Phytagoras: 
$S L=\sqrt{\left(S_{D}\right)^{2}-\left(\frac{1}{2} S_{T}\right)^{2}}$

$S L=27,71 \mathrm{~mm}$

Luas area aliran fluida disisi shell (As) :

$$
\begin{aligned}
& A_{s}=\frac{I D \times C \times B}{S_{T}} \\
& A_{s}=0,042 \mathrm{~m}^{2}
\end{aligned}
$$

Kecepatan aliran fluida disisi shell (Vh):

$$
\begin{aligned}
V_{h} & =\frac{Q_{h}}{A_{s}} \\
V_{h} & =6,43 \mathrm{~m} / \mathrm{s}
\end{aligned}
$$

Jarak A1 dan A2 :

$$
\left(\sqrt{S_{L}{ }^{2}+\left(\frac{1}{2} S_{T}\right)^{2}}\right)<\left(\frac{S_{T}+d_{0}}{2}\right)
$$

$$
22,62 \mathrm{~mm}<28 \mathrm{~mm} \rightarrow \text { Jarak } \mathrm{A}_{2}>\mathrm{A}_{1}
$$

Kecepatan maksimum aliran fluida disisi shell di area A2 :

$$
\begin{aligned}
V_{\max } & =\frac{S_{T}}{S_{D}-d_{o}} x V_{h} \\
V_{\max } & =25,72 \mathrm{~m} / \mathrm{s}
\end{aligned}
$$

Maka untuk bilangan Reynold Number:

$\operatorname{Re}_{\max }=\frac{\rho_{h} x V_{\max } x d_{0}}{\mu_{h}}$

$\operatorname{Re}_{\max }=6.052,42$

Rasio perpindahan panas konveksi (Nusselt Number) disisi shell :

$$
\begin{aligned}
& \overline{\mathrm{N}} \overline{\mathrm{U}}_{\mathrm{D}}=\mathrm{C}_{1} \times \operatorname{Re}_{\mathrm{Nas}}{ }^{0,4} \times \mathrm{xpr}_{\mathrm{h}}{ }^{0,36} \times\left(\frac{\mu_{\mathrm{h}}}{\mu_{\mathrm{c}}}\right)^{1 / 4} \\
& \overline{\mathrm{N}} \overline{\mathrm{U}}_{\mathrm{D}}=1.300,34
\end{aligned}
$$

Koefisien konveksi disisi shell :

$$
\begin{aligned}
& \overline{h_{h}}=\frac{\overline{N u_{D} x} k_{h}}{d_{o}} \\
& \overline{h_{h}}=7.585,32 \frac{\mathrm{W}}{\mathrm{m}^{2} \mathrm{~K}}
\end{aligned}
$$

Koefisien gesek disisi shell:

$$
\begin{aligned}
& f=\left[0,79 x \ln \left(\operatorname{Re}_{D, \max }\right)-1,64\right]^{-2} \\
& f=0,036
\end{aligned}
$$

Kehilangan panas mayor disisi shell:

$$
\begin{aligned}
& h_{l, \text { mavor }}=f\left(\frac{N_{t} \times L}{2}\right)\left(\frac{\left(V_{h}\right)^{2}}{d_{0} \times 2 \cdot g}\right) \\
& h_{l, \text { mavor }}=199,14 m
\end{aligned}
$$

Kehilangan panas minor disisi shell:

$$
\begin{aligned}
& h_{l, \text { minor }}=\frac{N_{t} \cdot k \cdot V_{c}^{2}}{2 g} \\
& h_{l, \text { minor }}=132,76 \mathrm{~m}
\end{aligned}
$$

Kehilangan panas total disisi shell:

$$
\begin{aligned}
& h_{l, \text { total }}=h_{l, \text { mavor }}-h_{l, \text { minor }} \\
& h_{l, \text { total }}=66,38 \mathrm{~m}
\end{aligned}
$$

Penurunan tekanan disisi shell:

$$
\begin{aligned}
& \Delta p \text { shell }=N_{t} \cdot L \cdot \rho_{h} \cdot \frac{V_{h}{ }^{2}}{2 g} x f \\
& \Delta p \text { shell }=8.265,20 \frac{N}{m^{2}}
\end{aligned}
$$

Luas aliran permukaan sisi dalam tube:

$$
\begin{aligned}
A_{i} & =\frac{\pi}{4} \cdot d_{i}{ }^{2} \cdot L \cdot N_{t} \\
A_{i} & =0,048 \mathrm{~m}^{2}
\end{aligned}
$$

Luas aliran permukaan sisi luar tube:

$$
\begin{aligned}
& A_{o}=\frac{\pi}{4} \cdot d_{0}{ }^{2} \cdot L \cdot N_{t} \\
& A_{o}=0,057 \mathrm{~m}^{2}
\end{aligned}
$$

Koefisien Perpindahan Panas Menyeluruh/Overall Heat Transfer (Uo):

$$
\begin{aligned}
& U_{0}=\frac{1}{\frac{A_{0}}{A_{i} h_{i}}+\frac{A_{0} \ln \left(d_{0} / d_{i}\right)}{2 \pi \cdot k L}+\frac{1}{h_{h}}} \\
& U_{0}=3.945,27 \frac{\mathrm{W}}{\mathrm{m}^{2} K}
\end{aligned}
$$

Perpindahan Panas Total (Qo):

$$
\begin{aligned}
& Q_{o}=U_{o} \cdot A_{o} \cdot \Delta T_{L M T D} \\
& Q_{o}=3.029,14 \mathrm{~W}
\end{aligned}
$$

Number of Transfer Unit (NTU): 
Ibrahim, H..., Analisa Dampak Penurunan Kinerja Lube Oil ...

$$
\begin{aligned}
& N=N T U=\frac{U_{o} \cdot A_{o}}{C_{\min }} \\
& N T U=15,28 \frac{W \cdot s}{\mathrm{~kJ}} \\
& n=N^{-0,22} \\
& n=0,5489\left(\frac{W \cdot s}{\mathrm{~kJ}}\right)
\end{aligned}
$$

Gambar 9. Analisa Efektifitas Panas Rata's ( $\varepsilon$ ) Data Logsheet Posisi 03 Juni 2017

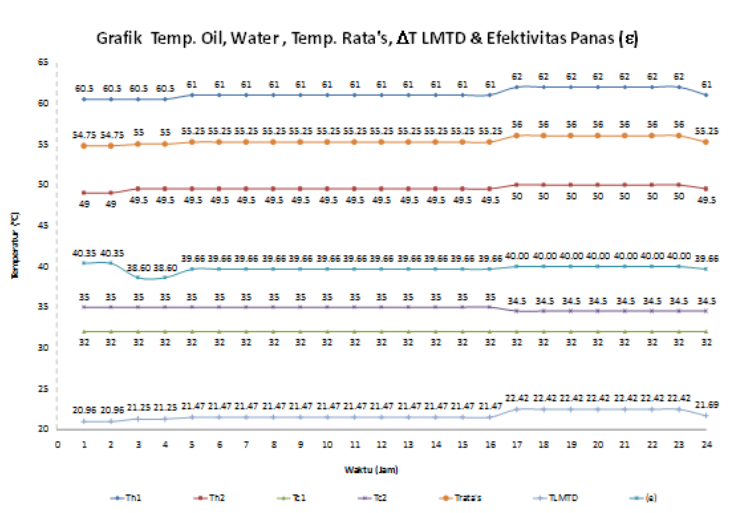

Gambar 10. Analisa Efektifitas Panas Rata's ( $\varepsilon$ ) Data Logsheet Posisi 04 Juni 2017

$$
C_{c}=68.948,55 \frac{\mathrm{J}}{\mathrm{s} . \mathrm{K}} \rightarrow C_{c}=68,95 \frac{\mathrm{kJ}}{\mathrm{s} . \mathrm{K}}
$$$$
C_{c}=m_{c} \cdot C p_{c}
$$

Rasio kapasitas panas (Cr):

$$
\begin{aligned}
C_{r} & =\frac{C_{\min }}{C_{\max }} \\
C_{r} & =21,35 \%
\end{aligned}
$$

Nilai efektifitas lube oil cooler:

$$
\begin{aligned}
& \epsilon=\frac{T h_{1}-T h_{2}}{T h_{1}-T c_{1}} \\
& \varepsilon=66,67 \%
\end{aligned}
$$

Berdasarkan pengamatan sample data logsheet pada lube oil cooler sejak tanggal 03 s/d 07 Juni 2017, telah diperoleh data temperatur rata-rata (Th), ?TLMTD, efektifitas panas (?) dan telah dilakukan perhitungan dapat disajikan dalam beberapa grafik (gambar $9,10,11,12$, dan 13).

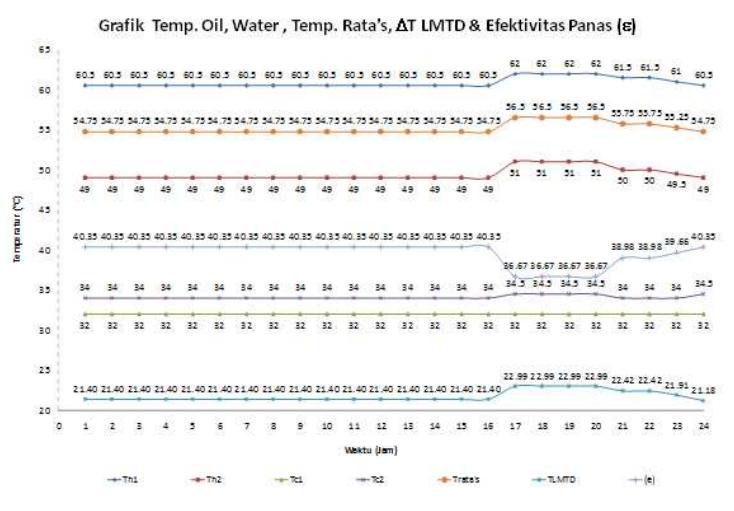

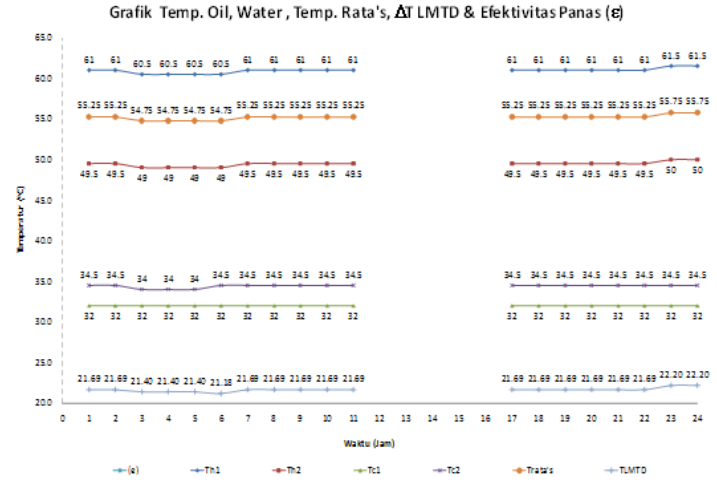

Gambar 11. Analisa Efektifitas Panas Rata's ( $\varepsilon$ ) Data Logsheet Posisi 05 Juni 2017

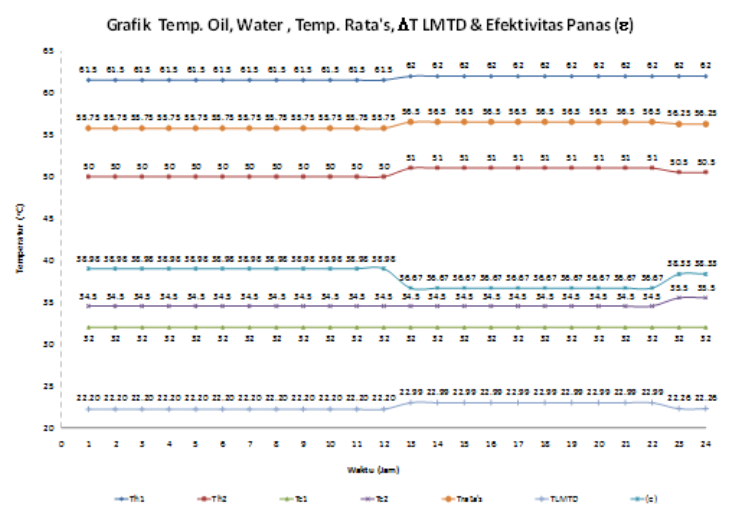

Gambar 12. Analisa Efektifitas Panas Rata's ( $\varepsilon$ ) Data Logsheet Posisi 06 Juni 2017 


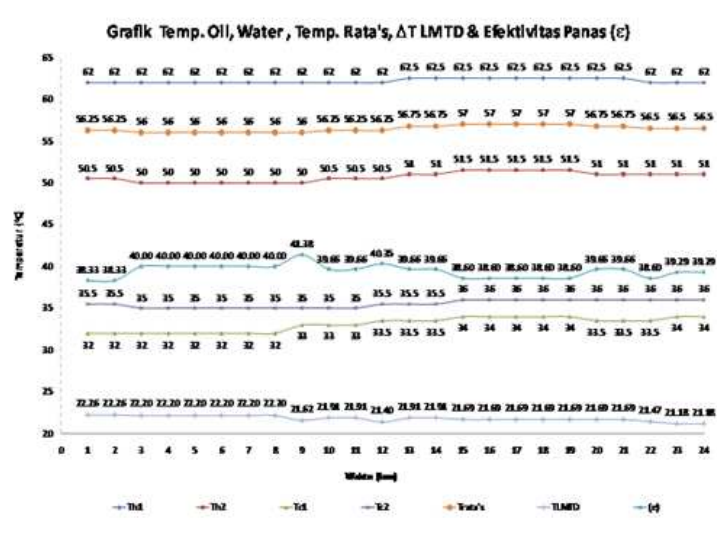

Gambar 13. Analisa Efektifitas Panas Rata's $(\varepsilon)$ Data Logsheet Posisi 07 Juni 2017

Berdasarkan hasil perhitungan dengan menggunakan data spesifikasi lube oil cooler terpasang diperoleh efektivitas lube oil cooler (?) diperoleh sebesar 66,67\%. Namun setelah dilakukan pengamatan sample data (logsheet) harian lube oil cooler diperoleh efektivitas panas rata's per hari (?) seperti diperlihatkan pada tabel 2.

Tabel 2. Nilai efektifitas panas rata-rata per hari dalam \%

\begin{tabular}{||c|c|ccc||}
\hline \multicolumn{5}{|c||}{ Nilai efektifitas panas rata's per hari ( $\overrightarrow{(\vec{E})}$ dalam \% } \\
\hline 03 Jun 2017 & 04 Jun 2017 & 05 Jun 2017 & 06 Jun 2017 & 07 Jun 2017 \\
\hline 39,59 & 39,73 & 39,73 & 37,96 & 39,44 \\
\hline
\end{tabular}

Efektifitas panas rata's tertinggi terjadi pada tanggal 04 dan 05 Juni 2017 sebesar 39,73\% dan terendah pada tanggal 06 Juni 2017 sebesar 37,96\%. Berikut akan dijelaskan secara singkat terkait alur proses kerja lube oil cooler. Fluida pendingin (demin water) masuk melalui pipa inlet cooling water, mengalir ke dalam melalui pipa-pipa tube pada bagian atas (temperatur awal Tc1). Kemudian air pendingin bergerak terus mengalir pada pipa-pipa tube bagian atas menuju ke pipa-pipa tube bagian bawah hingga menuju pipa outlet cooling water. Temperatur fluida pendingin yang keluar dari pipa outlet cooling water selanjutnya akan berubah menjadi Tc2 setelah menyerap panas dari minyak pelumas selama berada didalam lube oil cooler.

Disisi lain pada waktu yang bersamaan, fluida minyak pelumas masuk melalui pipa inlet lube oil pada bagian bawah (temperatur awal Th1), untuk diarahkan bersinggungan dengan sisi luar pipa-pipa tube yang berisi air pendingin. Kemudian minyak pelumas panas bergerak terus mengalir pada sisi shell bersirkulasi menyelimuti seluruh pipa-pipa tube yang juga dibatasi dengan sekat plate baffel didalam lube oil cooler tersebut. Minyak pelumas akan terus mengalir hingga menuju pipa outlet lube oil dan temperatur fluida minyak pelumas yang keluar dari pipa outlet lube oil menurun menjadi Th2 setelah melepas panasnya ke pipa-pipa tube selama berada didalam lube oil cooler. Lebih jelasnya dapat diamati pada gambar 14 .

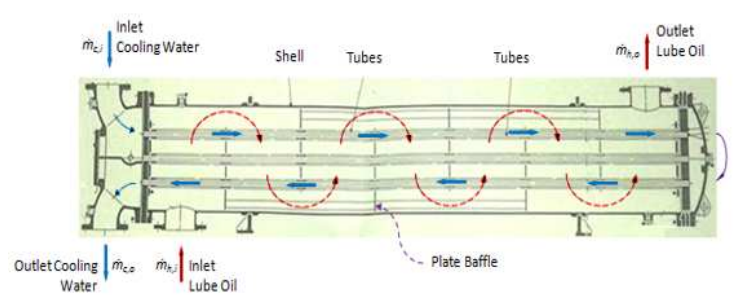

Gambar 14. Alur Proses Kerja Fluida Masuk dan Keluar pada Lube Oil Cooler

Beberapa permasalahan lube oil cooler yang umum terjadi dilapangan dan dapat menyebabkan turunnya performance lube oil cooler, diantaranya: Kebocoran pada pipa-pipa tube, menyebabkan tekanan fluida air pendingin menurun. Selain itu sebagian 
air pendingin akan bercampur ke minyak pelumas yang berakibat merusak kualitas minyak maupun sebaliknya. Terjadi penyumbatan, pengera- kan, pengendapan kotoran pada pipa-pipa tube oil cooler akibat kualitas air pendingin yang kurang baik. Hal ini disebabkan sumber utama air pendingin di PLTU Sektor Pembangkitan Belawan berasal dari air laut Belawan yang telah melalui tahapan pemurnian. Namun demikian endapan kotoran dari air pendingin masih mungkin dapat dijumpai pada pipa-pipa tube oil cooler maupun peralatan lainnya. Endapat kotoran dapat berupa microbiologi, scale, deposit, korosi yang dapat menyumbat atau mempersempit lubang pipa-pipa tube lube oil cooler yang akan menurunkan kinerja lube oil cooler. Laju perpindahan panas pada lube oil cooler akan menurun sehingga proses penyerapan panas dari minyak pelumas ke demin water akan menurun, akibatnya temperatur kerja minyak pelumas turbin menjadi sulit dikontrol.

Terjadi penurunan tekanan pada pompa supply air pendingin, kerusakan pada pompa juga dapat disebabkan oleh terjadinya penyumbatan, pengerakan, pengendapan kotoran pada saluran masuk dan keluar pompa, casing bagian dalam pompa, impeller atau kebocoran pada packing pompa.

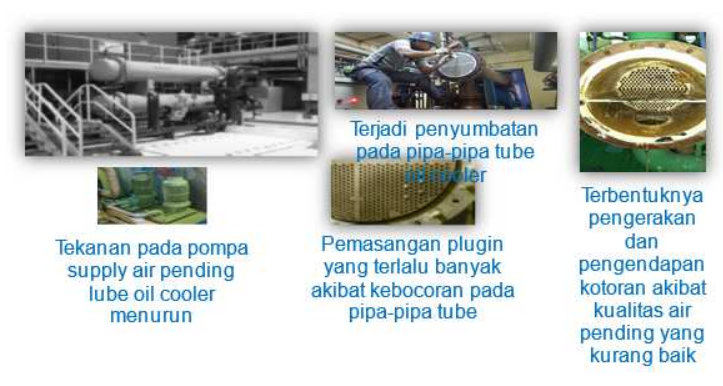

Gambar 15. Permasalahan pada Lube Oil Cooler yang umum terjadi

Beberapa bentuk upaya pemeliharaan rutin dan penyelesaian masalah yang umum dilakukan pada lube oil cooler seperti diatas, antara lain: untuk mengatasi kebocoran pipa-pipa tube adalah dengan menyumbat ujung pipa tube yang bocor (plugging) agar tidak dapat dialiri air pendingin. Namun demikian pemasangan plugging harus sesuai Standar Operasional Prosedur (SOP) yang ditetapkan dan tidak boleh melebihi batas maksimal tertentu karena akan mengurangi jumlah aliran pipa penyalur air pendingin sehingga penyerapan panas dari minyak pelumas ke air pendingin akan menurun.

Pembersihan secara rutin berkala pada pipa-pipa tube yang tersumbat akibat endapan kotoran dari kualitas air pendingin yang kurang baik, pengerakan pada casing bagian dalam lube oil cooler, maupun bagian lainnya. Pemurnian air pendingin harus dijaga kualitasnya agar tidak merusak instalasi lube oil cooler dan peralatan lainnya. Pembersihan pada pipa-pipa tube, casing bagian dalam maupun bagian sulit lainnya dapat dilakukan dengan menggunakan jacking water pump dan sesuai Standar Operasional Prosedur (SOP) yang ditetapkan.

Pengecekan secara berkala pada pompa supply air pendingin apabila tekanannya mengalami gejala penurunan. Permasalah pompa yang sering terjadi seperti penyumbatan, pengerakan, pengendapan kotoran pada saluran masuk dan keluar pompa, casing bagian dalam pompa, impeller, keausan pada bearing pompa, atau kebocoran 
pada packing pompa dan sesuai Standar Operasional Prosedur (SOP) yang ditetapkan.

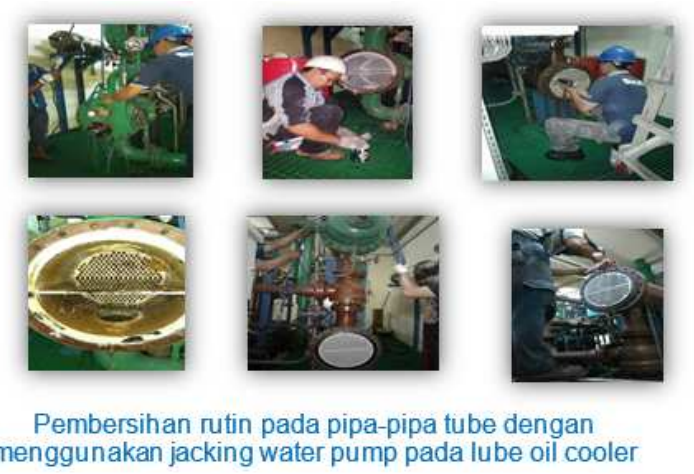

Gambar 16. Pemeliharaan Rutin pada Lube Oil Cooler

\section{KESIMPULAN}

Berdasarkan rumusan masalah, hasil penelitian dan analisa data pada lube oil cooler turbin di PLTU unit 3 berkapasitas 65MW PT PLN (Persero) Sektor Pembangkitan Belawan di atas, disimpulkan beberapa hal berikut:

- Proses kerja lube oil cooler dengan fluida pendingin demin water sangat efektif digunakan untuk mengontrol temperatur kerja minyak pelumas turbin di PLTU Unit 3 berkapasitas 65MW. Mengontrol temperatur minyak pelumas dapat memperpanjang umur operasional unit dan minyak pelumas yang digunakan.

- Koefisien perpindahan panas disisi shell (hh) sebesar 7.585,32 W/m2K, kehilangan panas total disisi shell (hl,total) sebesar 66,38m. Koefisien perpindahan panas disisi tube (hi) sebesar 11.460,98 W/m2K dan kehilangan panas total disisi tube (hl,total) sebesar 14,82m.
- Spesifikasi material pipa-pipa tube terpasang adalah Alumunium Brass (CuZn28Sn). Efektivitas lube oil cooler (?) berdasarkan spesifikasi terpasang sebesar $66,67 \%$, namun berdasarkan data pengamatan (logsheet) harian lube oil cooler pada unit turbin sejak tanggal $03 \mathrm{~s} / \mathrm{d}$ 07 Juni 2017 diperoleh Efektifitas panas rata's tertinggi terjadi pada tanggal 04 dan 05 Juni 2017 sebesar $39,73 \%$ dan terendah pada tanggal 06 Juni 2017 sebesar 37,96\%.

- Untuk mengatasi setiap permasalahan pada lube oil cooler, langkah awal yang harus dilakukan adalah identifikasi setiap permasalahan dengan berpedoman pada Standar Operasional Prosedur (SOP) yang ditetapkan.

\section{PENGHARGAAN}

Ucapan terima kasih kepada Program Studi Teknik Mesin, Politeknik Negeri Medan yang telah membantu dan mendukung penelitian ini sehingga dapat diselesaikan dengan baik. Kepada para kolega yang telah membantu dengan dukungan materil dan moril kepada peneliti, sehingga penelitian ini dapat diselesaikan dengan baik.

\section{REFERENCES}

[1] D. F. Senjaya and H. Napitupulu, "Analisa Pengaruh Water Wash Terhadap Performansi Turbin Gas Pada PLTG Unit 7 
Ibrahim, H.., Analisa Dampak Penurunan Kinerja Lube Oil ...

Paya Pasir PT. PLN Sektor Pembangkitan Medan," Jurnal Ilmu, vol. 7, no. 3, pp. 32-48, 2013.

[2] D. R. Pitts and L. E. Sissom, Perpindahan Kalor, Jakarta: Erlangga, 2011.

[3] G. Sumarno and S. Priyoatmojo, "Perpindahan Panas Pada Gas Turbine Closed Cooling Water Heat Exchanger di Sektor Pembangkitan PLTGU Cilegon," Jurnal IImu, vol. 11, no. 3, pp. 122-141, 2015.

[4] J. P. Holman, Perpindahan Kalor, Jakarta: Erlangga, 1994.

[5] K. A. Wibowo and A. B. Dwiyantoro, "Studi Numerik Peningkatan Cooling Performance pada Lube Oil Cooler Gas Turbine yang Disusun Secara Seri dan Paralel dengan Variasi Kapasitas Aliran Lube Oil," Jurnal Ilmu, vol. 3, no. 2, pp. 78-89, 2014.

[6] PLN, Heat Exchanger, Medan: Pusat Pendidikan dan Pelatihan, 2010.

[7] T. M. Sitompul, Alat Penukar Kalor, Jakarta: Rajawali Press, 1993. 